\title{
PROPOSAL FOR THE MANAGEMENT OF SOLID WASTE GENERATED IN A UNIVERSITY CAMPUS: A CASE STUDY
}

\author{
BETHY MERCHÁN-SANMARTIN ${ }^{1,2,3}$, PATRICIA N. ALMEIDA ${ }^{1,2}$, MAYRA BROCEL ${ }^{1,2}$, \\ BRYAN R. PINTO ${ }^{1,2}$, KAREN CÓRDOVA $^{1,2}$, ANTHONY MULLO $^{1,2}$, \\ PAÚL CARRIÓN-MERO ${ }^{1,2,3}$ \& EDGAR BERREZUETA ${ }^{4}$ \\ ${ }^{1}$ Facultad de Ingeniería en Ciencias de la Tierra, Escuela Superior Politécnica del Litoral, Ecuador \\ ${ }^{2}$ Centro de Investigaciones y Proyectos Aplicados a las Ciencias de la Tierra, \\ Escuela Superior Politécnica del Litoral, Ecuador \\ ${ }^{3}$ Geo-Recursos y Aplicaciones GIGA, Escuela Superior Politécnica del Litoral, Ecuador \\ ${ }^{4}$ Departamento de Infraestructura Geocientífica y Servicios, Instituto Geológico y Minero de España, Spain
}

\begin{abstract}
Sustainable development goals $3,6,7,9,11,12,13,14$, and 15, promoted by the United Nations, address the issue of waste management as a basis for preserving ecosystems. This paper states the management of recyclable and non-recyclable solid waste generated by 19,032 people on the university campus of the Escuela Superior Politécnica del Litoral (ESPOL) in Ecuador. The objective of this study is to present proposals for the integral management of solid waste in ESPOL, based on the estimation of per capita production (PCP in $\mathrm{kg} / \mathrm{hab}$-day). The applied methodology was: (i) revision of the Ecuadorian legal and technical regulations applicable to the Guayaquil canton on solid waste management; (ii) analysis of the current status of ESPOL and characterization of solid waste; (iii) projection of the population growth of the university and estimation of the PCP of residues; (iv) development of proposals for the collection, handling, processing, transformation, transport and final disposal of recyclable and non-recyclable solid waste; (v) presentation of solid waste management proposals. According to the result, the production of solid waste in ESPOL reaches $780.31 \mathrm{~kg} / \mathrm{day}$ ( 28,481 ton/year); the classification and quantification of waste indicate that $61.82 \%$ is organic, followed by plastic with $18.79 \%$ and paper with $13.05 \%$, the remaining $6.34 \%$ is metal, glass, tetra pack, electronics, and other types. Among the proposals for the management and use of waste includes capacitation for people who work at the campus and the continuous disclosure to the students. To advance towards the goal of zero waste and circular economy, first, it is necessary to achieve the sustainable environmental culture of the entire polytechnic community.
\end{abstract}

Keywords: proposals, management, solid waste, recyclable, sustainability.

\section{INTRODUCTION}

The generation and disposal of solid waste have been a problem since humanity began and its inadequate management causes diverse environmental, social, economic, and public health impacts [1]. As an answer, sustainable development implies sound management of all wastes to minimize waste generation through prevention, reduction, recycling, and reuse. In general, the range of products and materials in circulation present numerous challenges at all stages of the waste management journey. Effective waste management as a whole should be based on the correct identification and subsequent sorting of waste materials. However, there remains a huge amount of uncertainty over how different types of waste should be sorted and distributed [2]. Developed societies generally produce large amounts of municipal solid waste (e.g., organic, plastic, metal, paper, electronic) [3]. Once generated, wastes must be managed through reuse, recycling, recovery, and disposal.

The challenges imposed on cities such as non-generation, reduction, reuse, recycling, treatment, and environmentally adequate allocation of growing volumes of waste are also matters that concern universities [4]. In particular, in this study, university campus produces 
waste that requires proper management [5]. According to Tangwanichagapong et al. [6], universities require services and infrastructures, including waste management at the scale of a small city due require services like those, including accommodation, transportation, shopping, leisure, and waste management [7].

The university leaders in environmental and social responsibility should be to consider integrated waste management as a key element for their sustainable development [8]. Universities and colleges are obliged by state and international organizations to adopt sustainable development strategies in all their operations, in order to have a positive impact on the socio-economic and environmental well-being of their communities [9]. The universities must ensure more sustainability through the integration of three strategies, namely: University Environmental Management System (EMS); public participation and social responsibility; and promoting sustainability in teaching and research [10]. The first step to implement an efficient waste management system on a university campus is to know the composition, quantity, and recycling potential of the waste it generates [11], [12].

Several universities across the globe already have successful cases of solid waste management, in terms of waste characterization and the implementation of actions to reduce waste generation. Some examples are Universitat Jaume I in Spain [13], the University of Brasilia in Brazil [14], the Autonomous University of Baja California in Mexico [15], Harvard University in the United States [16], Catholic University of Chile [17], Prince George campus of the University of Northern British Columbia in Canada [18], the University of British Columbia in Canada [19], among other. In the case of Shenyang University in China, they have implemented in their campus, a ground source heat pump with less frequently gas to operate their heat pumps; a system wastewater recycling, it includes cascade reuse, waste minimization, and source reduction; integrated solid waste management (such as the collection of discarded PET - polyethylene terephthalate- bottles, etc.), green education and research [20]. According to Evans et al. [21], engaging university students in real-world sustainability challenges is worthwhile [22].

Circular economy (CE) is a concept currently promoted by the EU, by several national governments including China, Japan, UK, France, Canada, The Netherlands, Sweden, and Finland as well as by several businesses around the world [23]. A circular economy is based on the principles of designing out waste and pollution, keeping products and materials in use, and regenerating natural systems [22].

In the case of the Gustavo Galindo Campus of ESPOL (Guayaquil, Ecuador) (Fig. 1), it currently has a program in place to guarantee its sustainability. The General Services area and the Physical Infrastructure Management, concerned about the generation of waste and solid waste, seek their efficient management. So far, students who do community service practices have developed previous work and collected data on waste and solid waste.

In addition, there are little-known initiatives by the students and teachers at the university that have not been adequately disseminated or have not been carried out in an institutional manner.

The objective of this work is to develop a plan for the integral and sustainable management of the non-hazardous solid waste that is generated in ESPOL, based on the correct characterization of these and the participation of the 19,032 people that make up the university community. In addition, the definition of intervention actions for the short, medium, and long term is contemplated for scenarios with and without COVID.

\section{METHODOLOGY}

To carry out this work, 5 phases were considered, which can be seen in Fig. 2: 


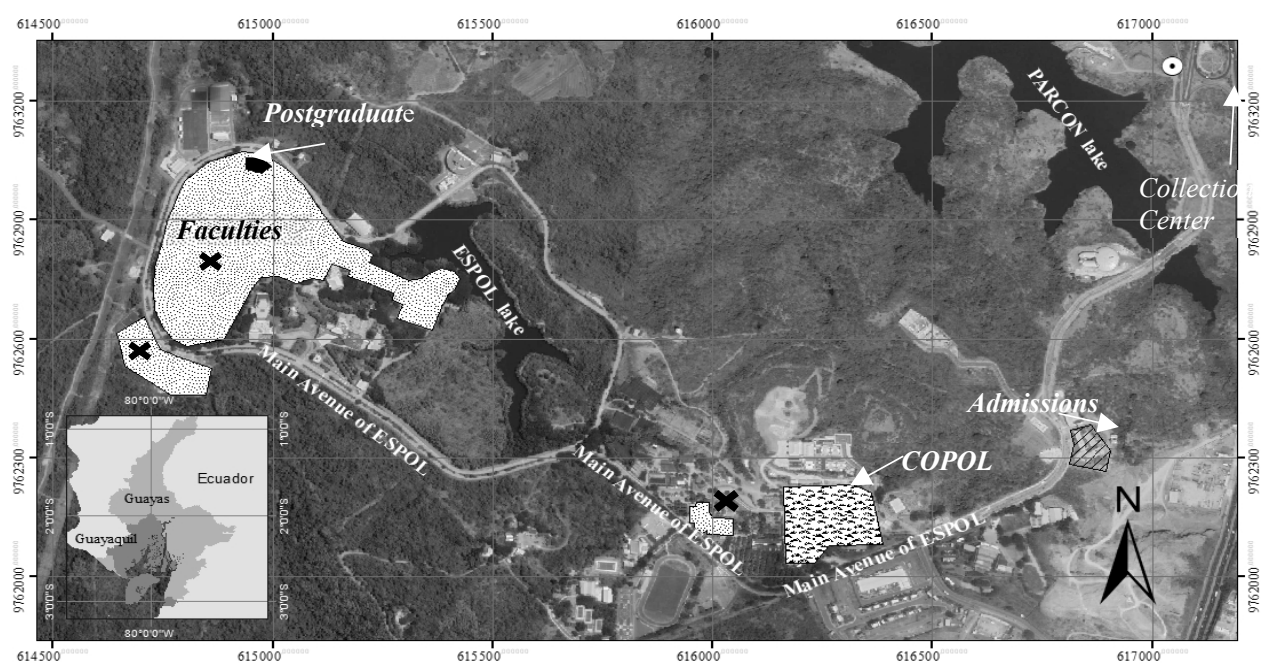

Figure 1: View of the ESPOL University Campus.

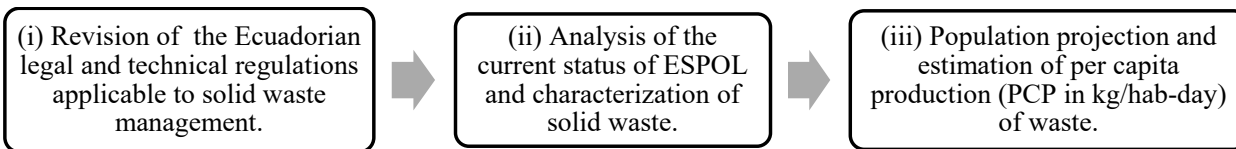

(i) Revision of the Ecuadorian applicable to solid waste management. (ii) Analysis of the and characterization of solid waste. (iii) Population projection and estimation of per capita of waste.

Figure 2: Methodology to be followed for the proposal of the solid waste management plan.

In the first phase, the Ecuadorian legal and technical regulations applicable to the Guayaquil canton on solid waste management were reviewed to analyzing information that deals with the correct management of solid waste from its generation at the source to its treatment and final disposal, as well as the degree of compliance by the university.

In the second phase, analysis of ESPOL's actions such as its Sustainability Program was carried out, with the aim of collecting information on the initiatives it has about solid waste management and the different activities that are already being carried out (interviews with the staff of the restaurants and reports of community practices). Finally, the waste generated in 5 of the 8 faculties was estimated for the year 2019. Thus, a projection was made to estimate the annual amount generated by the campus.

In the third phase, the analysis of the population of 2019 was carried out, having only data on the generation of garbage for that year; the projection of the future population, as well as the estimation of the PCP ESPOL. Based on data in 2019 the population of undergraduate students and faculties workers was obtained [24]; for students of admissions, polytechnic college (COPOL), and postgraduates, information was obtained from Cruz 
Cabrera and Hidalgo Calva [25]. In parallel, the data of future populations that are in the development of the Master Plan of Water and Sewerage of the ESPOL were analyzed, and the Special Zone of Economic Development (ZEDE) in an agreement with the Municipality of Guayaquil. To estimate the growth of this population, it was projected to 15 years.

In the fourth phase, proposals were made for the collection, transfer, handling, processing, transformation, transport, and final disposal of the solid waste. The proposals presented are easy to apply and implement, with relevant impact; under low budget and active participation of students, workers, teachers, administrators, and managers of the university.

Finally, the plan developed was presented to the Area of Sustainability and Management of Physical Infrastructure of the ESPOL. In addition, this plan was presented to students from different faculties so that they can contribute their knowledge through community internships in semesters 1 and 2 of the period 2021-2022. Specifically, assigning students tasks related to the proposed waste management plan.

\section{RESULTS}

\subsection{Legal regulations}

Ecuadorian legal and technical regulations applicable to Guayaquil on waste management are shown in Table 1.

Table 1: Regulations for solid waste management in force in Ecuador.

\begin{tabular}{|c|c|c|}
\hline Points to solve & Normative & Article/Chapter \\
\hline \multirow{3}{*}{$\begin{array}{l}\text { Duties of citizens and } \\
\text { the correct management } \\
\text { of solid waste from its } \\
\text { generation to its final } \\
\text { disposal. }\end{array}$} & Constitution of the Republic of Ecuador. & 43,815 \\
\hline & $\begin{array}{l}\text { Organic Code of Territorial Organization and } \\
\text { Autonomy and Decentralization. }\end{array}$ & 186 \\
\hline & $\begin{array}{l}\text { Book VI, Annexes } 6 \text { of the Unified Text of } \\
\text { Secondary Environmental Legislation (TULSMA) }\end{array}$ & 3 \\
\hline \multirow{3}{*}{ Garbage collection bins } & NTE INEN 2841 & Anexo 1 \\
\hline & $\begin{array}{l}\text { Book VI, Annex } 6 \text { of the Unified Text of } \\
\text { Secondary Environmental Legislation }\end{array}$ & 4.4.4, 4.4.5 \\
\hline & Municipal Council of Guayaquil. & 14 \\
\hline $\begin{array}{l}\text { Storage, presentation, } \\
\text { transport in dump trucks } \\
\text { or similar solid waste }\end{array}$ & Ordinance of the municipal council of Guayaquil. & 13,1621 \\
\hline
\end{tabular}

\subsection{Analysis of the current status of ESPOL and characterization of solid waste}

The initiatives for solid waste management of ESPOL's Sustainability Program are shown in Table 2.

ESPOL has 85 non-hazardous solid waste collection stations. Each station is made up of three plastic buckets with a capacity of 195 liters each [26]. In contrast to the NTE INEN 2841 standard, which indicates the standardization of colors, the ESPOL uses colored containers: red (paper and cardboard), green (organic), and blue (plastics and glass) [27]. During the inspection, it was found that: (i) some containers had no relationship between the colors and the expected labels; (ii) that they are close to each other, their arrangement was not adequate since some were very full and others almost empty.

In 2019 the students of community service made the characterization in five of the eight faculties; without considering the restaurants, the following results were obtained (Table 3). 
Table 2: ESPOL initiatives for solid waste management.

\begin{tabular}{|l|c|}
\hline Project's name & Year \\
\hline $\begin{array}{l}\text { Baseline survey of campus waste management as a buffer zone for the } \\
\text { Prosperina Protective Forest }\end{array}$ & 2019 \\
\hline Hammermill & 2020 \\
\hline $\begin{array}{l}\text { Baseline survey of the entire process and machinery used for the } \\
\text { composting of the Bosque Protector la Prosperina Program. }\end{array}$ & 2019 \\
\hline Metal bottle locations for source separation, PET & 2019 \\
\hline $\begin{array}{l}\text { Proposal for the implementation of a solid waste management system at } \\
\text { the Gustavo Galindo Campus }\end{array}$ & 2019 \\
\hline Campus Gustavo Galindo ESPOL Recycling Proposal, phase I & 2019 \\
\hline "Innovation" final presentation - phase II & 2019 \\
\hline Solid waste management guide in canteens and cafeterias & 2009 \\
\hline
\end{tabular}

Table 3: Characterization of garbage in FIEC, FCSH, FICT, FIMCP and FADCOM.

\begin{tabular}{|l|c|c|c|c|c|c|c|}
\hline Type & $\begin{array}{c}\text { FIEC }^{1} \\
(\mathrm{~kg} / \text { day })\end{array}$ & $\begin{array}{c}\text { FCSH }^{2} \\
(\mathrm{~kg} / \text { day })\end{array}$ & $\begin{array}{c}\text { FICT }^{3} \\
(\mathrm{~kg} / \mathrm{day})\end{array}$ & $\begin{array}{c}\text { FIMCP }^{4} \\
(\mathrm{~kg} / \mathrm{day})\end{array}$ & $\begin{array}{c}\text { FADCOM }^{5} \\
(\mathrm{~kg} / \mathrm{day})\end{array}$ & \multicolumn{2}{|c|}{ Total } \\
\cline { 7 - 9 } & $(\mathrm{kg} /$ day $)$ & $\%$ \\
\hline Organics & 13.58 & 14.10 & 54.65 & 80.91 & 34.47 & 197.71 & 61.82 \\
\hline Plastics & 12.39 & 5.50 & 20.95 & 12.78 & 8.48 & 60.10 & 18.79 \\
\hline Paper & 12.26 & 9.75 & 5.80 & 7.45 & 6.49 & 41.75 & 13.05 \\
\hline Metals & 1.45 & 0.35 & 1.80 & 1.34 & 0.26 & 5.20 & 1.63 \\
\hline Glass & 2.20 & 0.72 & 2.70 & 1.82 & 2.8 & 10.24 & 3.20 \\
\hline Tetrapak & 0.55 & 0.15 & 0.30 & 0.14 & 0.34 & 1.48 & 0.46 \\
\hline Electronics & 0.23 & 0.00 & 0.00 & 0.25 & 0.31 & 0.79 & 0.25 \\
\hline Others & 1.20 & 0.27 & 0.00 & 0.31 & 0.77 & 2.55 & 0.80 \\
\hline $\begin{array}{l}\text { Total } \\
\text { (kg/day) }\end{array}$ & 43.86 & 30.84 & 86.2 & 105 & 53.92 & \multicolumn{2}{|c|}{319.82} \\
\hline
\end{tabular}

${ }^{1}$ Faculty of Engineering in Electricity and Computing.

${ }^{2}$ Faculty of Social and Humanistic Sciences.

${ }^{3}$ Faculty of Engineering ini Earth Sciences.

${ }^{4}$ Faculty of Engineering in Mechanics and Production Sciences.

${ }^{5}$ Faculty of Art, Design and Audiovisual Communication.

\subsection{Population projection and estimation of per capita production}

(PCP in kg/hab-day) of waste

For the estimation of the ESPOL population in the year 2035, 4 methods were used: arithmetic, exponential, geometric, and of simple interest (as shown in Fig. 3). Then the distribution plots were made and the value of $\mathrm{R}^{2}$ was obtained (a statistical measure that explains how close the data are to the adjusted regression line). With this, was determined that the arithmetic and exponential methods were the ones that best followed the trend, therefore, in the end, the average of these two values was calculated. To this value, was added the population of the ZEDE, which gave a total of 23,449 people.

$$
\begin{gathered}
\text { Población } 2019=19,032 \text { people } \\
\text { Population } 2035=\text { average }(\text { arithmetic m.: exponential m. }) \\
\text { Population } 2035=(20,903: 22,610)=21,757
\end{gathered}
$$




$$
\text { Total }=19032 \text { people }
$$

Population $2035=$ students $2035+$ population ZEDE 2035.

$$
\text { Population } 2035=21,757+1,692=23,449 \text { people }
$$

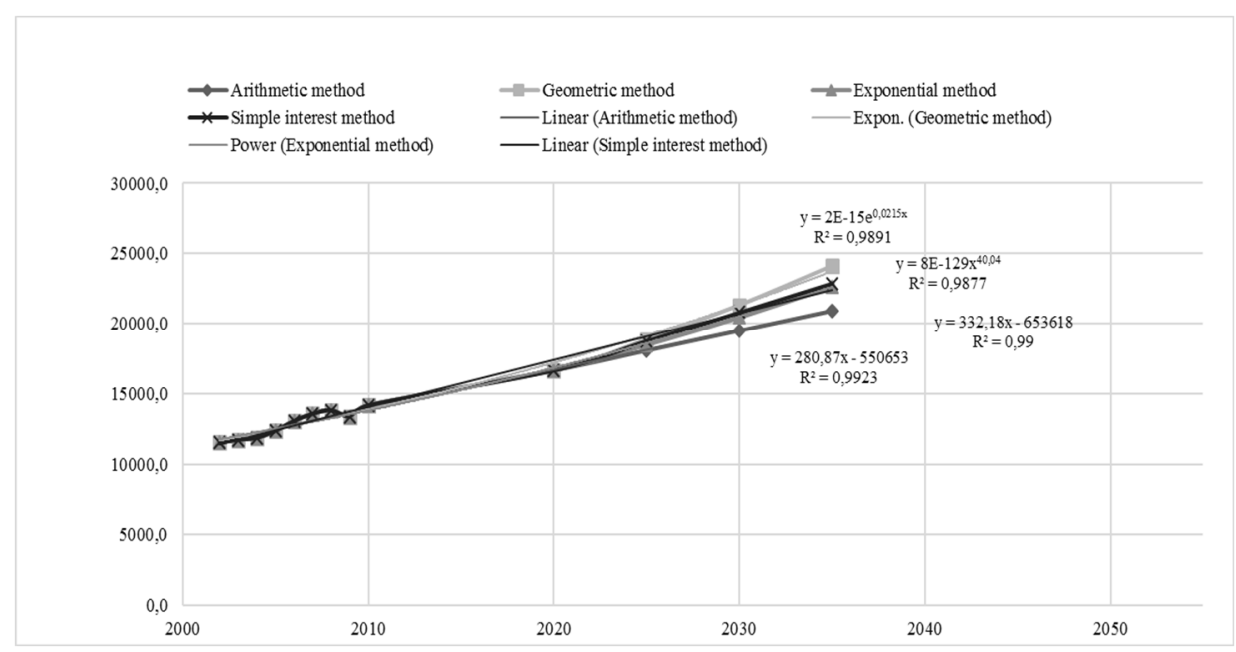

Figure 3: Estimation of the growth of the population.

With the population data and the production in $\mathrm{kg} /$ day of the year 2019, the PCP of the 5 faculties and the total production of the ESPOL that are observed in Table 4 were obtained. For the total PCP, 2 results were found, the first, $0.041 \mathrm{~kg} / \mathrm{hab}$-day, was obtained by dividing the total production in $\mathrm{kg}$ /day for the total population of the 5 faculties; while the second value, $0.050 \mathrm{~kg} / \mathrm{hab}$-day, was obtained from the average of the PCP of the 5 faculties.

\begin{tabular}{|c|c|c|c|c|c|}
\hline N. & Faculties & $\begin{array}{c}\text { Total } \\
\text { (hab.) }-2019\end{array}$ & $\begin{array}{c}\text { Production } \\
\text { (kg/día) }\end{array}$ & $\begin{array}{c}\text { PCP } \\
\text { (kg/hab-day) }\end{array}$ & $\begin{array}{c}\text { Mean PCP } \\
\text { (kg/hab-day) }\end{array}$ \\
\hline 1 & FICT & 1,030 & 86.2 & 0.084 & \multirow{5}{*}{0.050} \\
\hline 2 & FADCOM & 720 & 53.92 & 0.075 & \\
\hline 3 & FIMCP & 1,975 & 105 & 0.053 & \\
\hline 4 & FIEC & 2,173 & 43.86 & 0.020 & \\
\hline 5 & FCSH & 1,917 & 30.84 & 0.016 & \\
\hline & Total & 7,815 & 319.82 & 0.041 & \\
\hline
\end{tabular}

Table 4: Solid waste production by faculty.

To obtain 2019 daily and annual garbage production generated in other faculties, COPOL, admissions, and postgraduate; The PCP of 0.041 and $0.050 \mathrm{~kg} / \mathrm{hab}$-day was multiplied by the total population in 2019 for each of them, see Table 5 .

To obtain the daily and annual production of 2035, the PCP of 0.041 and 0.050 were multiplied by the total population in 2035 . The production in $\mathrm{kg}$ /day was calculated for 365 days of the year is instead of 260 days (working days), because it is in the extreme event (Table 6). 
Table 5: Solid waste production in different areas of ESPOL in 2019.

\begin{tabular}{|l|c|c|c|c|c|}
\hline \multirow{2}{*}{ Areas } & \multirow{2}{*}{$\begin{array}{c}\text { Habitants } \\
\text { (hab.) }-2019\end{array}$} & \multicolumn{2}{|c|}{ PCP $(0.041 \mathrm{~kg} / \mathrm{hab}$-day) } & \multicolumn{2}{c|}{ PCP $(0.050 \mathrm{~kg} / \mathrm{hab}$-day) } \\
\cline { 3 - 6 } & & $\begin{array}{c}\text { Production } \\
\text { (kg/day) }\end{array}$ & $\begin{array}{c}\text { Production } \\
\text { (ton/year) }\end{array}$ & $\begin{array}{c}\text { Production } \\
\text { (kg/day) }\end{array}$ & $\begin{array}{c}\text { Production } \\
\text { (ton/year) }\end{array}$ \\
\hline Faculties & 11,662 & 478.14 & 174.52 & 583.10 & 212.83 \\
\hline COPOL & 1,256 & 51.50 & 18.80 & 62.80 & 22.92 \\
\hline Pre-university & 4,769 & 195.53 & 71.37 & 238.45 & 87.03 \\
\hline Postgrade & 1,345 & 55.15 & 20.13 & 67.25 & 24.55 \\
\hline Total & 19,032 & 780.31 & 284.81 & 951.60 & 347.33 \\
\hline
\end{tabular}

Table 6: Projected production of solid waste generated in ESPOL in 2035.

\begin{tabular}{|c|c|c|c|c|}
\hline $\begin{array}{c}\text { Habitants } \\
\text { (hab.) }\end{array}$ & $\begin{array}{c}\text { PCP } \\
\text { (kg/hab-day) }\end{array}$ & $\begin{array}{c}\text { Days of } \\
\text { year }\end{array}$ & $\begin{array}{c}\text { Production } \\
\text { (kg/day) }\end{array}$ & $\begin{array}{c}\text { Production } \\
\text { (ton/year) }\end{array}$ \\
\hline \multirow{2}{*}{23,449} & 0.041 & \multirow{2}{*}{365} & 961.41 & 350.91 \\
\cline { 2 - 3 } \cline { 4 - 5 } & 0.050 & & $1,172.45$ & 427.94 \\
\hline
\end{tabular}

Additionally, the average PCP was calculated between 0.041 and $0.050 \mathrm{~kg} / \mathrm{hab}$-day, to obtain a standard PCP figure that serves to compare ESPOL's production with other universities (Fig. 4).

PCP at other universities

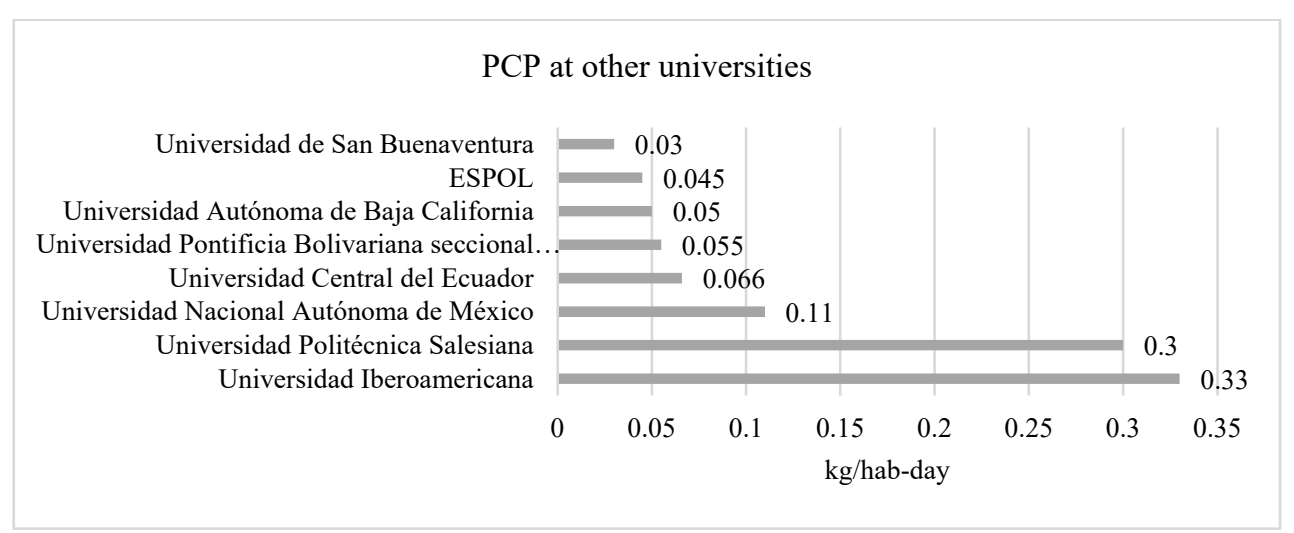

Figure 4: PCP at other universities.

3.4 Proposals' development for the collection, handling, processing, transformation, transport, and final disposal of solid waste

3.4.1 Proposals on waste management in open areas and food place of ESPOL

1. Definition of color and type of garbage can for the different areas.

Trash liners in the same color as the bins must be provided (Fig. 5).

2. Selection of collection points and waste collection centers

a) Reduce the number of collection points and replace old containers with new ones. 
b) Paint and label waste collection points that are lacking in maintenance.

c) Build a collection center for recyclable waste to separate, package and sell them.

d) Identification of waste from cleaning grease traps.

e) The Municipality of Guayaquil through Ordinance of 12-23-2010, recommends that "they must use the lemon green cover, 1.5 thousandths of an inch, mixing the accumulated fat with sand and lime".

3. Enabling deposits for organic waste.

Restaurants must have an exclusive cold deposit to store these wastes until they are collected by the collection car, thus avoiding bad odors.

4. Waste and residue control

Have a record of the garbage that originates daily, this record will be made by the people who will transport the garbage to the collection center.

5. Staff training aware of the new waste collection provisions and the mandatory use of personal protective equipment (as shown in Table 7).

6. Acquisition of machinery and appropriate equipment.

Change the current vehicle for another with a capacity greater than $1,000 \mathrm{~kg}$ that does not allow the spillage of waste. It must have internal compartments, to be able to separate the garbage.

7. Implementation of methods and schedules

a) In the dining rooms, plastic bottles, lids, papers, cardboard, etc. should be washed, so that they can be recycled. Then, the waste must be located in each bin.

b) Conduct a survey with general services personnel to agree on the waste collection schedule and discuss the materials to be used for collection.

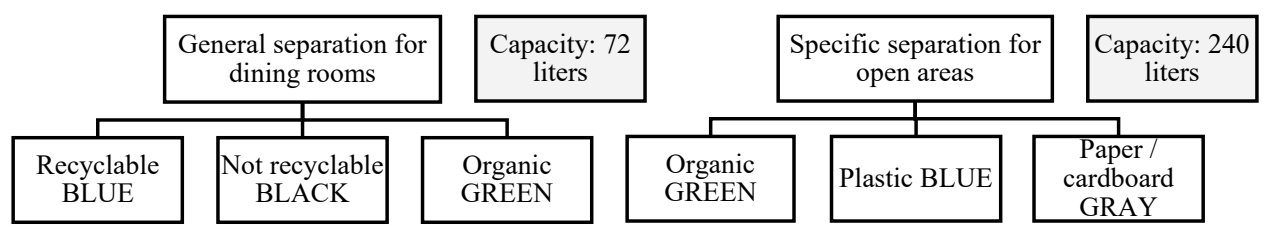

Figure 5: Color of trash cans and covers for dining rooms and open areas of ESPOL.

Table 7: Personal protective equipment.

\begin{tabular}{|l|l|l|l|}
\hline Uniform & Gloves & Footwear & Respirator \\
\hline $\begin{array}{l}\text { Jean pants; long sleeve t-shirt, light } \\
\text { color; overalls or apron; legionnaire } \\
\text { type cap, resistant and waterproof. }\end{array}$ & $\begin{array}{l}\text { ALY4960 } \\
\text { Power cut }\end{array}$ & $\begin{array}{l}\text { Rubber shoes } \\
\text { Rubber }\end{array}$ & $\begin{array}{l}\text { Filter mask } \\
\text { Organic gas } \\
\text { respirator. }\end{array}$ \\
\hline
\end{tabular}

3.4.2 Proposals on the integral management for PET plastic waste

1. Installation of metal stations

a) Location of 35 recycling stations (metal bottles) around the entire campus [24], [26]. 
b) Measurements: $1.60 \mathrm{~m}$ high and $0.75 \mathrm{~m}$ wide.

c) Materials: Galvanized closing mesh and smooth rod.

d) It must have a label that identifies its numbering in sequence.

e) Each bottle will include an infographic with the types of bottles allowed.

2. Assignment of waste transfer tasks

a) Students designated by competent authorities, such as student associations, will be in charge of cleaning the recycled bottles on a weekly basis at the stations of each faculty. For this, they must have garbage bags and PPE. After cleaning them, they will crush them in order to reduce their volume and they will collect them again in plastic bags that must be temporarily stored in each faculty.

b) The general services staff will be in charge of collecting and placing the bottles at the PARCON collection center on a weekly basis and the recycling company will be in charge of collecting the PET material from the same center.

3. PET waste management monitoring: Community internship students must also monitor the weight of PET plastic that will be sold to the recycling company so that sales and income from this activity are controlled.

\subsection{Management proposals of the solid waste}

Two main axes were addressed: "Cultural Change Program" and "Solid Waste Management". The activities indicated in each axis will be carried out in the short (2 to 4 months), medium (4 to 8 months), and long-term (8 to 12 months), which were organized as follows (Table 8).

\section{DISCUSSION OF RESULTS}

Regarding regulations, ESPOL needs to apply more rigorously the guidelines for the efficient management of solid waste. From the analysis of the 85 stations, some do not receive enough garbage that could be collected for transport. This could be because there is not enough public influx in those sectors, so they should relocate to a more suitable place.

About the population, it was found that FICT is the second faculty with the smallest population and, even so, it presents the highest garbage production in $\mathrm{kg} / \mathrm{day}$. One explanation is that many of the students circulate through this faculty, due to the forced path to the campus bus station.

The waste management plan presented in this work, when compared with that of other universities [13]-[19], presents similar procedures regarding: (i) knowledge of the generation and composition of waste and (ii) the use of tools monitoring control to establish the traceability of waste (origin, evolution in school years). In other words, corroborating the importance of a plan of improvement measures that, on the one hand, increases selective collection and, on the other, minimizes the waste generated.

The best way to promote environmental culture is through the creativity of students and teachers, to create awareness in the polytechnic community, and thus, adopt new habits in the handling of garbage. It is important to note that later it is intended to address the management of liquid waste and emissions into the atmosphere. Specifically, in the new period 2021-2022, with the participation of the new community work groups. 
Table 8: Plan of activities.

\begin{tabular}{|c|c|c|c|c|}
\hline & Activities & Months & Careers & Profiles \\
\hline \multirow{5}{*}{ 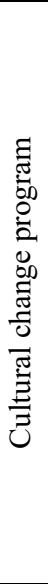 } & $\begin{array}{l}\text { Elaboration of the social advertising } \\
\text { campaign for the different areas of } \\
\text { ESPOL. }\end{array}$ & 4 & \multirow{3}{*}{$\begin{array}{l}\text { Graphic } \\
\text { Design, } \\
\text { Production for } \\
\text { Media }\end{array}$} & \multirow{3}{*}{$\begin{array}{l}\text { Junior Illustrator, Junior } \\
\text { Diagrammer, Junior Art } \\
\text { Director, Junior Creative } \\
\text { Writer, Junior Digital } \\
\text { Designer, Junior } \\
\text { Graphic Designer, } \\
\text { Junior Post-Producer, } \\
\text { Junior Community } \\
\text { Manager }\end{array}$} \\
\hline & $\begin{array}{l}\text { Induction and training for new } \\
\text { entrants and the polytechnic } \\
\text { community in general. }\end{array}$ & 4 & & \\
\hline & $\begin{array}{l}\text { Launch and control of the social } \\
\text { advertising campaign in the } \\
\text { different áreas (services in general) }\end{array}$ & 12 & & \\
\hline & $\begin{array}{l}\text { Follow-up of restaurants, cafes, and } \\
\text { bars to update information and } \\
\text { verify the correct recycling } \\
\text { processes. }\end{array}$ & 4 & $\begin{array}{l}\text { Civil } \\
\text { Engineering }\end{array}$ & Technical Drawing \\
\hline & $\begin{array}{l}\text { Creation of an internal mechanism } \\
\text { to encourage workers to participate } \\
\text { in waste collection. }\end{array}$ & 2 & $\begin{array}{l}\text { Business } \\
\text { Management }\end{array}$ & Administrative Analyst \\
\hline \multirow{5}{*}{ 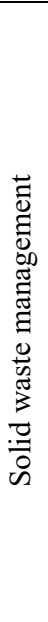 } & $\begin{array}{l}\text { Identification and characterization } \\
\text { of non-hazardous solid waste (in } \\
\text { times of COVID). GIS }\end{array}$ & 4 & $\begin{array}{l}\text { Civil } \\
\text { Engineering }\end{array}$ & $\begin{array}{l}\text { Technical Drawing, } \\
\text { Hydraulics }\end{array}$ \\
\hline & $\begin{array}{l}\text { Relocation and/or signaling of } \\
\text { garbage collection stations at } \\
\text { strategic points and maintenance or } \\
\text { replacement of damaged cans. }\end{array}$ & 4 & $\begin{array}{l}\text { Mechanical } \\
\text { Engineering }\end{array}$ & $\begin{array}{l}\text { Mechanical } \\
\text { Maintenance Assistant }\end{array}$ \\
\hline & $\begin{array}{l}\text { Optimization of food handling } \\
\text { processes in restaurants. }\end{array}$ & 8 & $\begin{array}{l}\text { Food } \\
\text { Engineering }\end{array}$ & $\begin{array}{l}\text { Assistant in Food } \\
\text { Processing }\end{array}$ \\
\hline & $\begin{array}{l}\text { Creation of a management plan for } \\
\text { waste collected at campus stations. }\end{array}$ & 4 & $\begin{array}{l}\text { Civil } \\
\text { Engineering }\end{array}$ & Geotechnics \\
\hline & $\begin{array}{l}\text { Analysis of possible infiltration } \\
\text { point in the area where the } \\
\text { temporary recovery center will be } \\
\text { implemented. } \\
\text { Structural design of the temporary } \\
\text { recovery center. }\end{array}$ & 4 & $\begin{array}{l}\text { Geology, Civil } \\
\text { Engineering }\end{array}$ & $\begin{array}{l}\text { Geological Threats, } \\
\text { Structures }\end{array}$ \\
\hline
\end{tabular}

\section{CONCLUSIONS}

Ecuadorian and municipal regulations of the Guayaquil canton helped considerably in the elaboration of the proposals for the management of solid waste from ESPOL. By taking small steps, the great objective of having a zero-waste university can be achieved. That is why it must bet on cultural change and waste management that is maintained over time.

Organic waste and PET plastics are the ones with the highest production, the possibilities of use in the short-term proposals are directed to them; however, in the medium and long term, it seeks to recycle, reuse or produce energy with all waste.

ESPOL produced an approximate total of 285 to 347 tons of waste in 2019. For the future population of 23,449 people in 2035, a generation between 350 to 428 tons/year is expected, of which $80 \%$ is expected to be used sustainably. The average PCP in the university is $0.045 \mathrm{~kg} / \mathrm{hab}$-day, ranking it as the second-best among other universities in America. 
It is expected that the proposed change of color bins, stipulated by the INEN-2014, in the open áreas of ESPOL, Will achieve an acceptable response among students and workers, to create a differentiation of the garbage effectively.

The implementation of these proposals cannot be carried out if there is no commitment from each of the people who make up the polytechnic community. If we all collaborate for the good of the university, we will effectively be able to create good habits of differentiation from garbage, for which the cultural change program is the greatest challenge within the plan.

Finally, for 2021 it is intended to characterize liquid waste and emissions into the atmosphere, in such a way that new possibilities of use and/or creation of energy sources are achieved. With the implementation of this, it is intended that ESPOL University can become a zero-waste campus in the medium and long term.

\section{REFERENCES}

[1] Ojeda-Benítez, S., Aguilar-Virgen, Q., Taboada-González, P. \& Cruz-Sotelo, S.E., House hold hazardous waste as a potential source of pollution: A generation study. Waste Management and Research, 31(12), pp. 1279-1284, 2013.

[2] A simple illustrated guide to types of waste - Recycle Track Systems. https://www.rts.com/blog/a-simple-illustrated-guide-to-types-of-waste/. Accessed on: 27 Apr. 2021.

[3] Wastes|EPA's Report on the Environment (ROE)|US EPA. https://www.epa.gov/ report-environment/wastes. Accessed on: 27 Apr. 2021.

[4] Lemos, P.F.I., Silva, A.C.C.F.A. \& Moro, C.C., Environmental governance of solid waste in USP campuses: The university as a laboratory for environmental public policies. World Sustainability Series, pp. 577-585, 2018.

[5] Pike, L., Shannon, T., Lawrimore, K., McGee, A., Taylor, M. \& Lamoreaux, G., Science education and sustainability initiatives. International Journal of Sustainability in Higher Education, 4(3), pp. 218-229, 2003.

[6] Tangwanichagapong, S., Nitivattananon, V., Mohanty, B. \& Visvanathan, C., Greening of campus through waste management initiatives: Experience from a higher education institution in Thailand. International Journal of Sustainability in Higher Education, 18(2), pp. 203-217, 2017.

[7] Zhang, N., Williams, I.D., Kemp, S. \& Smith, N.F., Greening academia: Developing sustainable waste management at higher education institutions. Waste Management, 31(7), pp. 1606-1616, 2011.

[8] Barros, R.M. et al., Design and implementation study of a permanent selective collection program (PSCP) on a university campus in Brazil. Resources, Conservation and Recycling, 80, pp. 97-106, 2013.

[9] Adeniran, A., Nubi, A. \& Adelopo, A., Solid waste generation and characterization in the University of Lagos for sustainable waste management. Waste Management, 67, pp. 3-10, 2017.

[10] Alshuwaikhat, M. \& Abubakarb, I., An integrated approach to achieving campus sustainability: Assessment of the current campus environmental management practices, 2008.

[11] Armijo de Vega, C., Ojeda-Benítez, S. \& Ramírez, M.E., Solid waste characterization and recycling potential for a university campus. Waste Management, 28(Suppl. 1), pp. S21-S26, 2008.

[12] Kassaye, A.Y., Contemporary institutional solid waste management practices of Haramaya University, Eastern Ethiopia. African Journal of Science Technology Innovation and Development, 10(1), pp. 1-20, 2018. 
[13] Gallardo, A., Edo-Alcón, N., Carlos, M. \& Reanau, M., The determination of waste generation and composition is an essential tool to improve the waste management plan of a university. Waste Management, 53, pp. 3-11, 2016.

[14] Nolasco, E., Vieira Duraes, P.E., Pereira Gonçalves, J., de Oliveira, M.C., de Abreu, L.M. \& de Almeida, A.N., Characterization of solid wastes as a tool to implement waste management strategies in a university campus solid wastes as a tool. International Journal of Sustainability in Higher Education, 1(1), pp. 1-20, 2020.

[15] Velasco, M.E., Plan de Manejo para la Gestión Integral de Residuos Peligrosos, Considerando su Acopio, Almacenamiento, Transporte y Envío a Reciclaje, Tratamiento o Disposición Final. Universidad Autónoma del Estado de Baja California, Facultad de Ciencias Marinas, 2010.

[16] Inbar, Y., Hadar, Y. \& Chen, Y., Composting and recycling of organic wastes. Modern Agriculture and the Environment, pp. 341-362, 1993.

[17] Avendaño, D., Daniella, A. \& Bonomelli, C., El proceso de compostaje. Pontificia Universidad Católica de Chile, Facultad de Agronomía e Ingeniería Forestal, 2003.

[18] Smyth, D.P., Fredeen, A.L. \& Booth, A.L., Reducing solid waste in higher education: The first step towards 'greening' a University Campus. Resources, Conservation and Recycling, 54(11), pp. 1007-1016, 2010.

[19] Felder, M.A., Petrell, R.J. \& Duff, S.J., A solid waste audit and directions for waste reduction at the University of British Columbia, Canada. Waste Management and Research, 19(4), pp. 354-365, 2001.

[20] Geng, Y., Liu, K., Xue, B. \& Fujita, T., Creating a "Green University" in China: A case of Shenyang University. Journal of Cleaner Production, 16, pp. 13-19, 2013.

[21] Evans, J., Jones, R., Karvonen, A., Millard, L. \& Wendler, J., Living labs and coproduction: University campuses platforms for sustainability science. Current Opinion in Environmental Sustainability, 16, pp. 1-6, 2015.

[22] What is the circular economy? https://www.ellenmacarthurfoundation.org/circulareconomy/what-is-the-circular-economy. Accessed on: 27 Apr. 2021.

[23] Korhonen, J., Honkasalo, A. \& Seppälä, J., Circular economy: The concept and its limitations. Ecological Economics, 143, pp. 37-46, 2018.

[24] Sánchez, R.I.A. \& Bermúdez, R.A.G., Diagnóstico y propuesta de soluciones técnicas para El sistema de aguas servidas Del campus gustavo galindo, 2020.

[25] Cruz Cabrera, O.O. \& Hidalgo Calva, K.M., Plan Maestro de Agua Potable, Alcantarillado Sanitario y Pluvial para ESPOL, Guayaquil, 2021.

[26] Aguayo Vera, C.J. \& Icaza Hidalgo, E.B., Levantamiento de línea base de la gestión de desechos del campus como zona de amortiguamiento del bosque protector prosperina. Guayaquil, 2019.

[27] INEN, Gestión ambiental. estandarización de colores para recipientes de depósito y almacenamiento temporal de residuos sólidos. Requisitos, NTE INEN 2841: QuitoEcuador, 2014. 